\title{
Social Capital of Women Leaders in the Indigenous Community of Osing, East Java, Indonesia: A Feminist Ethnography Research
}

\author{
Neng Hannah ${ }^{*}$ \\ UIN Sunan Gunung Djati Bandung, Indonesia; e-mail: nenghannah@uinsgd.ac.id \\ * Correspondence
}

Received: 2020-10-08; Accepted: 2020-12-30; Published: 2020-12-30

\begin{abstract}
Female leaders have been around since ancient Indonesia. However, fewer women become leaders than men. Female leadership is considered successful when it follows male standards. The purpose of this research is to reveal the experience of women's leadership in the Osing Banyuwangi indigenous community. This research employs qualitative research with a feminist ethnographic approach. The findings of this study show that there are three female village heads in the Osing indigenous community, namely Kemiren village, Rejosari village, and Kampunganyar village. All three women have the capital they need to be elected and lead the community. The capital they owned both in the quality and quantity of the relationship network they transform and are in the form of economic capital, cultural capital, and social capital. In conclusion, this social capital is owned by the female leader herself and is not an extension of the power of the other party. These capitals make them able to face challenges typically attributed to women's leadership namely negative stereotypes and double burdens.
\end{abstract}

Keywords: Cultural capital; economic capital; indigenous; social capital; Women's leadership.

Abstrak: Pemimpin perempuan sudah ada sejak zaman Indonesia kuna. Namun, jumlah perempuan yang menjadi pemimpin lebih sedikit ketimbang laki-laki. Kepemimpinan perempuan dianggap sukses apabila mengikuti standar laki-laki. Mengungkap bagaimana kepemimpinan perempuan di masyarakat adat Osing Banyuwangi merupakan tujuan penelitian ini. Metode yang digunakan merupakan penelitian kualitatif dengan pendekatan etnografi feminis. Temuan dari penelitian ini ialah terdapat tiga kepala desa perempuan di masyarakat Osing yaitu Kepala Desa Kemiren, Kepala Desa Rejosari dan Kepala Desa Kampunganyar. Ketiganya memiliki modal sosial yang besarnya tergantung pada kualitas maupun kuantitas jaringan hubungan yang dibentuknya, ukuran kapital ekonomi, kapital budaya dan kapital sosial yang dimiliki. Kesimpulannya modal sosial ini dimiliki oleh pemimpin perempuan itu sendiri dan bukan perpanjangan kuasa dari pihak lain. Hal ini menjadilan mereka bisa menghadapi tantangan dalam khas dalam kepemimpinan perempuan yaitu stereotype negatif dan beban ganda.

Keyword: Kapital ekonomi, kapital budaya, kapital sosial, kepemimpinan Perempuan.

\section{Introduction}

In the context of Indonesian society, women being leaders is not a new phenomenon. Starting from the western tip of Aceh, South Sulawesi, some areas in the island of Java to the eastern tip of Indonesia, there are traces of women who become leaders (Saraswati, 2016). However, the number of female leaders is still small compared to men (Fanggidae, 2014). Based on the Indonesian regional elections in 2018, the number of women who became regional leaders increased (Hillman, 2018; Prihatini, 2018; Septina \& Arditama, 2018). Despite the increase, female leadership is often measured by male 
standards. Only women with standards that match male leadership are recognised for their success as leaders (Klenke, 1996).

Based on the results of the 2018 elections, the province that has the most female leaders is East Java. There were ten women selected. Starting from the Governor, Mayor of Surabaya, Regent of Probolinggo, Regent of Jember, Regent of Kediri, Mayor of Batu, Mayor of Probolinggo, Mayor of Jombang, Mayor of Mojokerto, and Regent of Bojonegoro (Tempo, 2018). The increase also occurred in women who were chosen as village heads. Banyuwangi, one of the regencies in East Java, based on the 2017 regional elections, out of 185 candidates, 17 are women (Kabar Banyuwangi, 2017).

Kemiren village, Banyuwangi Regency, East Java, is an indigenous village that the researcher visited during the Shortcourse of Social Critique organised by the Ministry of Education and Culture in collaboration with LP2M (Lembaga Penelitian dan Pengabdian Masyarakat - the Centre for Research and Community Development) of IAIN Jember (State Institute for Islamic Studies) from November 16 to December 15, 2018. Kemiren village is also called the Osing indigenous village which is led by a female village head. The head of the village named Ms. Lilik Yuliatin S.Ip. She welcomed us to the Osing traditional house owned by Mr. Pur, an influential indigenous figure. In her speech, she was very open with our presence to stay and do research. She explained the condition of Kemiren village or Osing traditional village and some programs carried out to promote indigenous tourism by remain committed to preserving the local culture (Direct observation, November 17, 2018).

After giving the speech that night, the village head returned to her house. I got the impression of several people, mostly the elders of the community, who cast doubt on the ability of the female village head and considered that she was not fit to be the village head. The issue of women's leadership in the Osing Indigenous people is interesting. Women are considered unfit to be politically viable by sociocultural appropriateness because they consider that politics is the men's public domain (Saputra \& Asih, 2017). Besides, several elected women who became regional leaders are appointed based on kinship and dynastic political relations (Fitriyah, 2018). Even though, many other women become leaders because of their ability in managing their intrapersonal, interpersonal, and cultural forces (Mangunsong, 2009). Several studies on women's leadership still tend to focus on urban feminist movements. Feminist studies of women's leadership in rural areas are still limited, as science also tends to see the rural areas as an object of policy, poverty, or development (Carolyn, 1996).

This article examines the leadership of women who become village heads in the Osing indigenous community of Banyuwangi Regency, East Java. This study investigates what kind of social capital, in this case, is the potential and actual resources owned by a woman who has an institutionalised social network that allows her to become leaders in her region. Do these potentials and resources belong to female leaders herself or are they an extension of other powers, especially men? What are the social capitals due to her economic capital, cultural capital, and social capital as leaders? This article will also discuss the challenges that women leaders specifically face.

This research uses a qualitative research design with a naturalistic and ethnographic feminist perspective. The main point lies in the effort to describe factual, actual, natural, emic, and holistic about the existence of women's leadership rather than on measurement. There are three purposes of feminist ethnography according to Reinharz (1992, p. 51) that the researcher uses. The first is to document the lives and activities of women leaders in the village (women's lives and activities). The second is to understand the experience of female leaders from the perspective of women's point of view. The third is to conceptualise the daily behaviour of female leaders (conceptualise women's behaviour) as their expression in a social context, all within the framework of gender relations.

In feminist ethnography, women's experiences and observations can be considered as knowledge. In most cultural studies, males are placed in significant positions, while females are almost in domestic areas (Humm, 1990). This is detrimental and dangerous because women are increasingly being justified into a powerless position in society. Employing a feminist ethnographic method, the researcher focuses on women, writes and analyses statements, and corrects male biases in their reports. It is an attempt at the deconstruction of understanding (Idrus, 2006; Venny, 2001). Through this approach, the experiences and knowledge of women who have been hidden to be raised to the surface and heard. Women go 
through their own experiences and analyse themselves so that they become visible (Holzner \& Saptari, 1994).

In this study, the researcher stayed with one of Osing indigenous families for one month from November 16 to December 15, 2018. After 'observing and listening' as two of the main data collection methods in ethnographic research (Idrus, 2006), in one week, the researcher found out that there were also the other two female village heads in the Osing Indigenous people namely Rejosari village and Kampunganyar village. Thus, this research was conducted in three villages in Glagah Subdistrict, Banyuwangi Regency to three female village heads of Kemiren village, Rejosari village, and Kampunganyar village, and purposively determined members of the community. As the researcher plays a significant role in ethnography, the researcher was directly involved in the various activities in the Osing community. Data collection was undertaken through observation and interviews. Caudle stated that unrestricted or direct observation was the first technique used (Caudle, 1994). The researcher also used semi-structured in-depth interview techniques. Qualitative interviews were generally not so structured. Data collection and analysis eventually merged simultaneously according to the dimensions of time. The researcher followed interview leads towards new topics or tried to build a deeper understanding by asking and clarifying questions.

\section{The Osing Indigenous Community in Banyuwangi, East Java: A General Overview}

The Osing people in Banyuwangi live mostly in nine sub-districts out of 24 subdistricts in Banyuwangi. The sub-districts are Banyuwangi (city), Rogojampi Giri, Glagah, Kabat, Songgon, Kluring, Singojuruh, and Genteng. Nowadays, efforts to maintain Osing culture and customs are decreasing although there are still villages that become the center of Osing culture. Nowadays, Osing Indigenous Communities that still survive reaches 14 communities, namely Mangir Indigenous Community, Cungkring Indigenous Community, Grogol Indigenous Community, Kemiren Indigenous Community, Glagah Indigenous Community, Andong Indigenous Community, Olehsari Indigenous Community, Mandaluka Indigenous Community, Bakungan Indigenous Community, Macan Putih Indigenous Community, Tambong Indigenous Community, Aliyan Community, and Alasmalang Indigenous Community.

These Indigenous communities have several common characteristics, namely: 1) they use Osing language, 2) They believe in a spirit protecting their places, 3) they are homogeneous because they live in the same village, 3) they preserve to perform the ritual to expel disturbing evil spirits from the village, 4) they follow their ancestral believe system, and 5) mostly, they work as farmers or carpenters (Indiarti \& Munir, 2016).

Out of 14 indigenous communities, Kemiren indigenous community in Glagah Sub-District, which became my residence during the Critical Social Shortcourse in 2018, is considered as one of the most steadfast in carrying out Osing tradition that has been inherited by their ancestors. In 1995, Basofi Sudirman, the Governor of East Java, designated this village as an Osing Indigenous tourism village. For the first time in the history of Kemiren indigenous village, a woman becomes its leader.

\section{Women Leaders in the Indigenous Community: Maximising Potential Resources}

There are three subjects of this research as my main data sources (table 1). They are Ms. Lilik Yuliatin, S.Ip as Kemiren Village Head, Ms. Hj. Nurhayati, S.Pd as Rejosari Village Head, and Ms. Siti Latifah Khairiah, S.H. as Kampunganyar Village Head.

The first woman leader is Ms. Lilik Yuliatin, S.Ip. She is 39 years old during this research took place. In the economic capital, she is the wife of a TNI and the child of a well-respected and wealthy family in the Osing Indigenous people. In cultural capital, she has graduated from university, undergraduate studies. Ms. Lilik is a smart woman and has good adaptability. Her motherly character can be the glue of various conflicts that exist in society. Due to social capital, as a daughter of Osing indigenous people figure, she gained an honorable position in the community. Her understanding and carrying out Osing culture in her daily life led her trusted. 
The second woman leader is Ms. Hj. Nurhayati, S.Pd, aged 45. In the economic capital, she comes from a rich family. His father and brother are the former of the head village. She has a businessman husband and a good family economy. In cultural capital, she also graduated from university. She has good interpersonal and intra-personal strength. She also active in community programs both Posyandu (Pos Pelayanan Terpadu - local community health service) and PKK (Program Kesejahteraan Keluarga - Indonesian Family Welfare Guidance Program) make her have a good managerial leadership capacity. Due to social capital, the privilege as a daughter and a sister of the village head made her gain various access and trust in community activities. Her concern for the community make her known and trusted to be the head of the village for two periods.

The third woman leader is Ms. Siti Latifah Khairiah, S.H. She is 36 years old. In the economic capital, she is a businesswoman who is heavily involved in village development especially related to the provision of goods and services village facilities and infrastructure. In cultural capital, she has graduated from university. Her strength as a leader comes from her supple and independent personality. As a bachelor of law, she also has good political strategy skills. As a businesswoman involved in village development projects, her figure is widely known by the people of Karanganyar village. The conflict between the four other village head candidates during the election made her win narrowly in the village head election.

Table 1 Information of three informants as the main resouces of the research

\begin{tabular}{|c|c|c|c|}
\hline $\begin{array}{l}\text { Informant's } \\
\text { name }\end{array}$ & $\begin{array}{l}\text { Village head of } \\
\text { Kemiren: Lilik Yuliatin } \\
\text { S.Ip (aged 39) }\end{array}$ & $\begin{array}{l}\text { Village head of Rejosari } \\
\text { Hj. Nurhayati, S.Pd } \\
\text { (aged } 45 \text { ) }\end{array}$ & $\begin{array}{l}\text { Village head of } \\
\text { Kampunganyar Siti Latifah } \\
\text { Khairiah, S.H (a single } \\
\text { mother, 36) }\end{array}$ \\
\hline $\begin{array}{l}\text { Economic } \\
\text { Capital }\end{array}$ & $\begin{array}{l}\text { Husband: a member of } \\
\text { the National military } \\
\text { forces. } \\
\text { Family: She came from a } \\
\text { rich and well-known } \\
\text { family in the indigenous } \\
\text { community. }\end{array}$ & $\begin{array}{l}\text { Husband: a } \\
\text { businessman. } \\
\text { Family: She came from a } \\
\text { rich family. Her father } \\
\text { and brother are the } \\
\text { former village head. }\end{array}$ & $\begin{array}{l}\text { Family: her family is a well- } \\
\text { known business owner } \\
\text { who is involved in many } \\
\text { development programs in } \\
\text { the community to provide } \\
\text { the goods and build the } \\
\text { facilities. }\end{array}$ \\
\hline $\begin{array}{l}\text { Cultural } \\
\text { Capital }\end{array}$ & $\begin{array}{l}\text { Hold a bachelor's } \\
\text { degree. She is good at } \\
\text { interpersonal interaction } \\
\text { and smart. She can } \\
\text { adapt easily to any } \\
\text { situation that is needed } \\
\text { mostly to solve the } \\
\text { conflict in the } \\
\text { community. }\end{array}$ & $\begin{array}{l}\text { Graduated from the } \\
\text { university. She has good } \\
\text { skills in communication } \\
\text { and active in many } \\
\text { village programs like } \\
\text { community health care } \\
\text { and community welfare } \\
\text { guidance program. She } \\
\text { has good managerial } \\
\text { skills. }\end{array}$ & $\begin{array}{l}\text { Hold a Bachelor's degree } \\
\text { from Law faculty. She is } \\
\text { independent and good at } \\
\text { interacting with others. She } \\
\text { also has a good political } \\
\text { strategy. }\end{array}$ \\
\hline Social Capital & $\begin{array}{l}\text { She is the daughter of a } \\
\text { prominent figure in the } \\
\text { Osing indigenous } \\
\text { community. Therefore, } \\
\text { she is respected in the } \\
\text { community and also } \\
\text { preserving the } \\
\text { indigenous traditions. }\end{array}$ & $\begin{array}{l}\text { She gained the privilege } \\
\text { as a daughter of the } \\
\text { previous village head } \\
\text { and make her get access } \\
\text { to many activities in the } \\
\text { community. She also } \\
\text { famous to care for the } \\
\text { traditions in the } \\
\text { community. }\end{array}$ & $\begin{array}{l}\text { She is a businesswoman } \\
\text { famous for her activities in } \\
\text { the community especially } \\
\text { in providing the goods and } \\
\text { infrastructure of the village. }\end{array}$ \\
\hline
\end{tabular}




\section{Several Factors of Women leaders' Capital}

As women elected in direct elections as village heads, the three female leaders show their capital in the form of women's actual potential and resources in becoming leaders is quite diverse. A person in a society may not individually solve the various problems at hand. Togetherness and good cooperation between all members of the community are needed. It is what gave rise to a concept called Social Capital (Rusydi, 2003).

To understand the structure and way of functioning of the social world, it is necessary to understand that capital in its various forms is not only related to the notion of capital from an economic point of view. There are many forms of potential derived from an economic point of view that is considered non-economic because they cannot directly optimise material benefits, even the potential is very important. Immaterial capital in the form of cultural capital and social capital usually follows the economic capital transaction. The three of them can be identified with one another in terms of their level of ease to be converted. Bourdieu (1986, p. 16) mentioned that capital can be represented into three kinds namely: economic capital, cultural capital, and social capital. The following explanation of the women's village heads refers to Bourdieu's capital in managing their representative as a village head.

\section{Economic Capital}

Economic capital is a form of social capital that can easily be converted into money. It can be institutionalised in the form of ownership rights. The three women leaders who were elected as village heads have good economic capital. Ms. Siti Latifah, Kampunganyar Village Head, is an economically strong entrepreneur woman. An interview with Ms. S (aged 38), a shop owner close to the village head's office, confirms it. She said, "yes, yes, she is a rich woman, a businesswoman and lucky, so she can be elected as the village head, even though the different result of votes is small" (interview with Ms. S, November 30, 2018). Several other women, who usually gather in the security post around the village while nurturing their children, also agreed as stated by Ms. M (aged 33), "she is a good person...she is also generous. Sometimes, she gave us money or daily need" (interview with Ms. M, November 30, 2018).

Two other female village heads, Ms. Lilik, and Ms. Nurhayati, also come from rich families and have a well-established position of the husband in the community. Ms. Sri (aged 41), the younger sister of the owner of the Osing house where the researcher lived, explained that "the family of the village head is rich. They like sharing their harvest" (Ms. Sri, Personal Communication, November 25, 2020). Besides, she further mentions that during the village election in 2013, the big family of Ms. Lilik distribute the daily needs of the community. Her family also usually provides the meal during the rituals. Meanwhile, the information regarding Ms. Nurhayati's economic capital came from the Village Secretary that the researcher interviewed. He stated "From generation to generation, [this family member] become a village head. She is also rich ..." (Ms. Nurhayati, Personal Communication, November 27, 2018).

\section{Cultural Capital}

According to Bordieu, there are three dimensions of cultural capital. They are embodied state, objectified state, and institutionalized state (Bourdieu, 1986, p. 17). The three female village heads in the Osing community have an attractive appearance. All three have a distinctive appearance. Ms. Lilik is more often dressed very motherly in a feminine fashion. Ms. Nurhayati usually looks more sporty with trousers and tunic so that it matches her active movements. Meanwhile, Ms. Siti Latifah, the youngest village head, is more millennial style with full makeup and fashionable fashion.

Based on their educational backgrounds, they hold Bachelors degree. It is a pretty good cultural capital in the middle of the Banyuwangi community's average length of schooling which is 7 to 12 years (equivalent to the first grade of junior high school) (BPS Banyuwangi, 2019). Also, there is the actual potential of these three women leaders. Ms. Nurhayati as Rejosari Village Head was a community health care service and a cadre in PKK for 12 years before becoming the village head. Besides, she 
actively participates in various social activities, village development, and religious activities. In particular, she has personal strength in assertiveness in leading, prioritising common interests rather than individuals, as well as being transparent in various village programs and budgets. So that the community trusts her to be the head of the village for two periods.

When asked what was her motivation to run for the village head in her first period of leadership? She replied that it was her extended family and community who had asked her to step forward as a village head. She explained, "During the first period I ran for office, there were many doubted especially religious leaders in the village. I was elected with a small number of winning votes. But during the second period, the majority of voters voted for me compared to the other candidates. Yes, I just go for it. (Ms. Nurhayati, Personal Communication, November 28, 2018).

Meanwhile, Ms. Siti Latifah as Kampunganyar village head is an alternative figure in the election of the existing village head. The villagers of Kampunganyar had previous conflicts so the previous village head was replaced by a Pejabat Sementara (PJS. or Temporary Officer). Her figure as an independent woman attracts people to choose her as a leader. When the researcher asked her about her motivation to participate in the election of the village head, she answered, "Yes, I just want to make changes. Can women be accepted as leaders by the community? In fact, I was accepted." (Ms. Siti Latifah, Personal Communication, December 1, 2018). In an in-depth interview, she talked about her non-Osing background. Her mother comes from Bandung and a father from East Java, but not from the Osing tribe. She and her extended family live in Karang Asem village, about $7 \mathrm{~km}$ from Kampunganyar village which she leads.

Meanwhile, Ms. Lilik Yuliatin, Kemiren village head, the researcher followed her on various occasions such as Endog-Endogan traditional ceremony to commemorate the birthday of the Prophet Muhammad, Barong dance performance, and Gandrung dance and show a polite figure and quite understand the Osing culture. In her speech during Endog-Endogan ceremony, she said, "I invite all people to live in mutual respect and work together to preserve the culture of Osing and imitate Rasulullah SAW [characters]" (Direct observation, December 9, 2018).

Since being elected as Kemiren village head in 2013, many changes have occurred during her leadership. The establishment of Bumdes (Badan Usaha milik Desa - Village Business Entity) in 2016 further encourage the arrival of domestic and foreign tourists who came to the Osing traditional village. In 2017, 4228 people visited the village. In 2018, it doubled to 8473, even in 2019 it reached 17,678. This number certainly has an impact on Bumdes income which also increases (Nursafitri, Pageh, \& Wirawan, 2020). Moreover, in 2019, the turnover of Pokdarwis (kelompok sadar wisata - the group of tourism concern), one of the fields in Kemiren Bumdes, reached 426,000,000 rupiahs (Nursafitri et al., 2020)

Ms. Lilik explained her motivation to run for the village head, "It is a call to do good things for the village where I and my family were born (Ms. Lilik, Personal Communication, November 25, 2018). The strong motivation is manifested not only in the form of increased village income but also in cultural preservation that getting stronger. Young children are used to learning gamelan and angklung Paglak (traditional music instruments). Every Sunday, there is a Barong dance performance accompanied by gamelan at the village office. All the dancers are teenagers aged 12-18 years old. The Bayuwangi Regional Government also positively supports cultural preservation, so that the Osing language becomes a local content curriculum starting from elementary school to junior high school level based on Banyuwangi Regency Regional Regulation No. 5 of 2007 concerning Local Language Learning at the Basic Education Level. Although in 2014 there was the Governor of East Java Regulation No. 19 of 2014 concerning Regional Language Subjects as Mulok (Muatan Lokal or local load) did not include the Osing language, practically, the teachers of elementary schools in Kemiren village still taught the Osing language (Arps, 2009; Duryat, 2019).

\section{Social Capital}

Social capital consists of two aspects, namely static and dynamic. The static aspect appears from social resources, while the dynamic aspect appears from the driving force (Pedroni, 2007; Portes \& 
Landolt, 1996; Schjoedt, Kraus, Schenkel, \& Garrison, 2009). Static social resources are the values passed from parents to children. One of them is the value of aristocrats that generate public respect. Then, it collaborates with the positive abilities of the individual which in turn generates public trust as in the case of two village heads, namely Ms. Lilik Yuliatin and Ms. Nurhayati. It is stated by Ms. S (42 years), an elementary school friend of Kemiren village head whose house is only 200 meters from the village office.

Ms. Lilik has a very influential husband. Although her husband is an official and a rich person, he likes to hang out with the village community. Moreover, his extended family is originally from Osing. They have extensive land and gardens that they like to share with the community. So that many have chosen her to be the village head. I was her elementary school friend. She was also quite smart (Ms. S, Personal Communication, November 26, 2018).

Meanwhile, information about Rejosari village head was based on an interview with the village secretary, Mr. S, he stated:

Ms. Nurhayati has a kindergarten school and she taught there before becoming head of the village. She is also active in village activities. His father was the former village head and followed by her older brother. So, she has a lot of support from the family." (Ms. S, Personal Communication, November 27, 2018).

According to Suhalik, the belief of the Osing indigenous people in choosing women as leaders can be closely related to the ideal figure of Banyuwangi women who are tough and have a high fighting spirit (Suhalik, 2009). Besides, the potential for gender equality and justice in Banyuwangi is a potential for social capital. Banyuwangi from a cultural aspect adheres to a bilateral kinship system, where daughters, and sons receive equal treatment to inherit family assets. According to Wiwin Indiarti, gender equality discourse has existed in the culture of the Osing community in Banyuwangi for a long time, as reflected in the play of Barong Kemiren (Indiarti \& Munir, 2016).

In various studies on leadership, two types of leadership emerged, namely transformational and transactional leadership. Unlike the previous view in leadership theory which contrasts between fulfilling the demands of the task as a leader and building good relationships with all parties related to leadership, in this case, transformational-transactional leadership is positioned as a continuum. It means that a leader can be both transactional and transformative. Transactional leadership is based on the exchange between the leader and followers. Followers are rewarded for specific achievements and performance. While transformative leaders display charisma and visionary by nature. Leading and motivating followers is more than just exchange and reward. Some literature concludes that female leaders are more transformative than male leaders (Fitriani, 2015). This argument is based on the idea that transformative leaders are more likely to guide subordinates and value discussion and socialisation. In general, women's ability to guide is better than men's.

The character of women's leadership as cited by Fanggidae (2014, p. 18) from the UN Department of Economic and Social Affairs are 1) concern for justice and the ethical dimensions of politics which are learned from the experiences of injustice they experienced as women; 2) the ability to make priorities and complete several jobs at once. They learn to balance duties in the household, work, and community; 3) aware of the importance of dialogue, consensus, and agreement; and 4) concern for the next generation. Apart from the various strengths described above, the three women leaders expressed the same strength, namely support from their families especially their husbands. Mangunsong (2009), p. 27) stated the same thing in his research on women leaders in the business sector who came from four ethnic groups. One of the conclusions stated: "in perceiving necessary things for a successful business, family support, especially from husbands and children, is the most important and main thing for the four ethnic groups studied, especially in decision making."

Two out of three female village heads felt that the support of their husbands greatly affected their performance as leaders. The types of support they receive include three forms. The first is directly 
supporting their work as women leaders. For example, the husband of Ms. Lilik Yuliatin participates in various social and traditional activities. Nurhayati's husband also provided support in the form of freedom in carrying out duties and sharing household roles. This is a good example for citizens in terms of working together in the family and social roles in society. The second is to become a discussion and consultation partner to solve problems and find solutions as a leader. The third is the support by allowing the woman leader to be involved in many activities outside their home. For these women, their husband's permission greatly eases their steps to become leaders.

Based on the explanation of the economic capital, cultural capital, and social capital above, we can see that potential resources and the actual form of social capital are owned by the leader of the women themselves. It is not an extension of the power of the others, especially men.

\section{The Challenges to Women Leadership}

The direct and democratic election of leaders such as village head elections that took place in the three villages studied, ultimately left problems caused by groups that are pro and contra. It happens to both male and female leaders to carry out their main duties and functions as village heads. If they do not have a strategy for reconciliation and the ability to act fairly, in general, contra opposition groups always present challenges in carrying out their main tasks and functions as village heads. The three village heads in this study also admitted it.

As female leaders in a male-dominated community, these three women leaders face specific challenges. First, regarding the assumption that women especially young ones cannot lead. It is the experience of Ms. Lilik who was 34 years old when she was inaugurated as Kemiren village head in 2013. Likewise, Ms. Nurhayati was 35 years old when she was elected in early 2018 and Ms. Siti Latifah in the 2017 election. This assumption mainly comes from traditional leaders and other community leaders who are dominated by men. The assumption often causes women leaders to feel insecure. The challenges faced can be categorised as a form of gender injustice, namely stereotypes (Fakih, 1996).

A stereotype is the labeling or marking of a certain group (Banaji, Hardin, \& Rothman, 1993; Shaw, 2012). In this case, the stereotype originates from the view that women are not capable of being leaders in society, and women who have a lot of activities outside the home are violating their 'nature' as women. It is also illustrated by the Program of Local Government Innovation for Communities in Aceh in their study of Women's Leadership in the Local Government Bureaucracy (Meeudon, 2015). One of the challenges identified in the study is the doubts of others in the bureaucracy about women's ability to lead. Women continue to undergo a process of socialisation about their inadequacies and ultimately limit their thoughts, giving rise to doubt and self-doubt in leading and making decisions. If they do something wrong, it is because they are women. This condition seems to emphasise that women are not worthy to participate or have a role in making important decisions even to improve their destinies.

Apart from stereotyping due to her young age and inability to lead, the negative stereotype of being a single mother was experienced by Siti Latifah, Karanganyar village head. In Indonesia, women who become janda, either divorced or widowed, are stigmatised in the community (Parker, Riyani \& Nolan, 2015). This condition made her stay at her parents' house which is far from the village she leads. Thus, she often arrives late at the village office. In February 2020, the village community facilitated by Badan Permusyawaratan Desa (BPD or the village council) conduct deliberations asking her to resign from her position (Teropong Timur Online, 2020). However, Siti Latifah can overcome this matter so she is still working as Karanganyar Village Head.

Second, regarding the division of time between social reproduction matters (raising children, taking care of the household, etc.) and its role as a leader in the community. Fakih (1996) classifies it as gender-based injustice where reproductive tasks in the household are considered women's duties. The reproductive tasks seem unproductive because they are economically unbeneficial. Thus, these tasks are regarded as second-class assignments. So in conditions where women also play a role in society as leaders, there is still a reluctance from men, in this case, husbands to take part in reproductive tasks. As a result, women who also play a role in public such as women leaders, experience a double burden and find it more difficult to share their time and energy. 
In Oxfam's (2011)research on women's leadership in communities supported by five organizations in Asia, they concluded that the root of the inequality problem lies in the household. Inequality occurs when the husband considers that as the head of the household, decision-making is his right and women should not violate cultural "values" and traditions that are unfair. One of the examples is the division of roles in the household. Such importance of this division of roles, the United Nations Conference reports the four women placed the division of labor in the household as the crucial thing for the household itself, and also for the consolidation of democracy.

From the above explanation about women leadership in the Osing indigenous community, it confirmed the simultaneous relation between Bourdieu's theory of capital (Bourdieu, 1986) and the reality experienced by those three women of the village heads. All three women have their capitals that functioned as the potentials that made them elected democratically as village heads. This habitus is proportionally used by these three women to develop their village and make significant changes for the development of the community. The analysis of this study is concentrated on the explanation of three capitals own by these three women namely economic capital, cultural capital, and social capital that transforms into the beliefs, the norms, and the values they integrated into their social networks.

\section{Conclusions}

Based on the above explanation, this study concludes that the leadership of three women in the Osing Indigenous community occurs because of the capital in the form of potential and actual resources they have. These capitals are owned by the three female leaders and not as an extension of the power of other parties, in this case, the men around them. The capital that exists in these three women leaders is in the form of economic capital, cultural capital, and social capital with various intensities and capacities. By having these capitals, they can overcome many challenges in women's leadership in the form of negative stereotypes and social injustice in the form of multiple burdens. This research implies that women have the opportunity to show their capability as community leaders either in the urban scenario or in the rural and indigenous community. They are also can compete with men to gain popularity and to be elected.

\section{References}

Arps, B. (2009). Osing Kids and the banners of Blambangan: Ethnolinguistic identity and the regional past as ambient themes in an East Javanese town. Wacana, 11(1), 1-38.

Banaji, M. R., Hardin, C., \& Rothman, A. J. (1993). Implicit stereotyping in person judgment. Journal of Personality and Social Psychology, 65(2), 272.

Bourdieu, P. (1986). The forms of capital. In J. Richardson (Ed.), Handbook of Theory and Research for the Sociology of Education (pp. 241-258). Westport, CT: Greenwood.

BPS Banyuwangi. (2019). Profil Pendidikan Kabupaten Banyuwangi Tahun 2013-2019. Retrieved October 14, 2020, from BPS Banyuwangi website: https://banyuwangikab.go.id/profil/profil-pendidikan.html

Carolyn, S. (1996). Gendered Fields Rural Women, Agriculture, And Environment. New York: Routledge.

Caudle, S. L. (1994). Using Qualitative Approaches. In J. S. Wholey, H. P. Hatry, \& K. E. Newcomer (Eds.), Handbook of Practical Program Evaluation. San Fransisco: Jossey-Bass Publishers.

Duryat, M. (2019). Politik Pelembagaan Bahasa Asing Melalui Pendidikan. Wahana Karya Ilmiah, 3(01).

Fakih, M. (1996). Analisis gender \& transformasi sosial. Jakarta: Pustaka Pelajar.

Fanggidae, S. (2014). Kepemimpinan Perempuan Manuju Kesetaraan Gender: Pembelajaran Perempuan Pemimpin di Desa Belu NTT. Yogyakarta: Institute for Research and Empowerment (IRE).

Fitriani, A. (2015). Gaya kepemimpinan perempuan. Jurnal Tapis: Jurnal Teropong Aspirasi Politik Islam, 11(2), 1-22.

Fitriyah, F. (2018). Politik Dinasti Pada Kandidasi Perempuan dalam Pilkada Serentak 2015 di Jawa Tengah. Jurnal Ilmu Sosial, 17(1), 39-52.

Hillman, B. (2018). The limits of gender quotas: women's parliamentary representation in Indonesia. Journal of Contemporary Asia, 48(2), 322-338.

Holzner, B., \& Saptari, R. (1994). Research Appoach. In B. Holzner (Ed.), Gender Methodology in Agricultural Project (pp. 122-131). Netherland: Departement of Gender Studies in Agricultural, Weagning University.

Humm, M. (1990). The Dictionary of Feminist Theory. Columbus: Ohio State University Press.

Idrus, N. I. (2006). Antropologi feminis: Etnografi, relasi gender dan relativisme budaya di Indonesia. Antropologi 
Indonesia, 30(3), 272-296.

Indiarti, W., \& Munir, A. (2016). Peran dan relasi gender masyarakat using dalam lakon Barong KemirenBanyuwangi. Patrawidya, 17(1), 81-103.

Kabar Banyuwangi. (2017). 14 Calon Kades Perempuan Ramaikan Pilkades Serentak di Banyuwangi. Retrieved December 19, 2019, from Kabar Banyuwangi website: https://www.kabarbanyuwangi.info/14-calon-kadesperempuan-ramaikan-pilkades-serentak-di-banyuwangi.html

Klenke, K. (1996). Women and leadership: A contextual perspective. NewYork: Springer Publishing Company, Inc.

Mangunsong, F. (2009). Faktor intrapersonal, interpersonal, dan kultural pendukung efektivitas kepemimpinan perempuan pengusaha dari empat kelompok etnis di Indonesia. Makara, Sosial Humaniora, 13(1), 19-28.

Meeudon, F. (2015). Empowering Women to Participate in Local Governance: Experience from the Field. Regional Workshop on Women's Participation in Local Governance - Exploring the Way Forward.

Nursafitri, H., Pageh, I. M., \& Wirawan, I. G. M. A. S. (2020). Perubahan Sosial Masyarakat Suku Osing di Desa Kemiren Sebagai Media Pebelajaran Sosiologi. Jurnal Pendidikan Sosiologi Undiksha, 2(3), 180-189.

Oxfam Novib. (2011). Women Leading Change: Experiences promoting women's empowerment, leadership, and gender justice. Den Haag: Oxfam Novib.

Pedroni, P. (2007). Social capital, barriers to production and capital shares: implications for the importance of parameter heterogeneity from a nonstationary panel approach. Journal of Applied Econometrics, 22(2), 429-451.

Portes, A., \& Landolt, P. (1996). The downside of social capital. Washington, DC: The American Prospect.

Prihatini, E. S. (2018). Indonesian young voters: Political knowledge and electing women into parliament. Women's Studies International Forum, 70, 46-52. Elsevier.

Reinharz, S. (1992). Feminist Methods in Social Research. Oxford: Oxford University Press.

Rusydi, S. (2003). Modal Sosial: Konsep dan Aplikasi. Jurnal Masyarakat Dan Budaya, 5(1), 16-49.

Saputra, I., \& Asih, N. W. (2017). Kepemimpinan perempuan dan pilkada serentak. ARISTO, 5(1), 141-162.

Saraswati, U. (2016). Kuasa Perempuan dalam Sejarah Indonesia Kuna. Sejarah Dan Budaya: Jurnal Sejarah, Budaya, Dan Pengajarannya, 10(1), 105-113.

Schjoedt, L., Kraus, S., Schenkel, M. T., \& Garrison, G. (2009). Exploring the roles of social capital and team-efficacy in virtual entrepreneurial team performance. Management Research News.

Septina, W. E., \& Arditama, E. (2018). Meningkatkan Partisipasi Politik Perempuan dalam PILGUB Jawa Tengah 2018. Jurnal Ilmu Politik Dan Pemerintahan, 4(2), 130-139.

Shaw, A. (2012). Do you identify as a gamer? Gender, race, sexuality, and gamer identity. New Media E Society, 14(1), 28-44.

Suhalik. (2009). Mengenal Sejarah dan Kebudayaan Banyuwangi. Banyuwangi: Pusat Studi Budaya Banyuwangi (PSBB).

Tempo. (2018). Pilkada 2018, 10 Perempuan Kepala Daerah di Jawa Timur. Retrieved October 15, 2019, from Tempo website: https:/cantik.tempo.co/read/1102384/pilkada-2018-10-perempuan-kepala-daerah-di-jawatimur/full\&view $=$ ok

Teropong Timur Online. (2020). Masyarakat Kampung Anyar Mengadukan Hasil Musyawarah Desa Kepada LSM Teropong Timur News Banyuwangi. Retrieved June 20, 2020, from Teropong Timur Online website: http://www.teropongtimur.co.id/2020/02/masyarakat-kampung-anyar-mengadukan.html

Venny, A. (2001). Feminisme Etnografis Perempuan Lokal: Kelompok Terbungkam dalam Penelitian Empiris. Jurnal Perempuan, 17, 123-131.

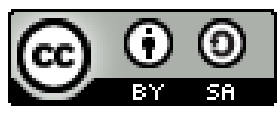

(C) 2020 by the authors. Submitted for possible open access publication under the terms and conditions of the Creative Commons Attribution (CC BY SA) license (https://creativecommons.org/licenses/by-sa/3.0/). 